\title{
Effects of Age and Breed on the Prevalence of Neospora caninum in Commercial Dairy Cattle from Pakistan
}

Author(s): Muhammad Mudasser Nazir, Azhar Maqbool , Muhammad Sarwar Khan, Afzal Sajjid , and David S. Lindsay

Source: Journal of Parasitology, 99(2):368-370. 2013.

Published By: American Society of Parasitologists

DOI: http://dx.doi.org/10.1645/GE-3173.1

URL: http://www.bioone.org/doi/full/10.1645/GE-3173.1

BioOne (www.bioone.org) is a nonprofit, online aggregation of core research in the biological, ecological, and environmental sciences. BioOne provides a sustainable online platform for over 170 journals and books published by nonprofit societies, associations, museums, institutions, and presses.

Your use of this PDF, the BioOne Web site, and all posted and associated content indicates your acceptance of BioOne's Terms of Use, available at www.bioone.org/page/terms_of_use.

Usage of BioOne content is strictly limited to personal, educational, and non-commercial use. Commercial inquiries or rights and permissions requests should be directed to the individual publisher as copyright holder. 


\title{
Effects of Age and Breed on the Prevalence of Neospora caninum in Commercial Dairy Cattle from Pakistan
}

\begin{abstract}
Muhammad Mudasser Nazir, Azhar Maqbool, Muhammad Sarwar Khan*, Afzal Sajjid†, and David S. Lindsay $\neq$, Department of Parasitology, University of Veterinary and Animal Sciences, Lahore 54600, Pakistan; *Department of Clinical Medicine and Surgery, University of Veterinary and Animal Sciences, Lahore 54600, Pakistan; †Veterinary Research Institute, Lahore 54810, Pakistan; ¥Department of Biomedical Sciences and Pathobiology, VirginiaMaryland Regional College of Veterinary Medicine, Virginia Tech, Blacksburg, Virginia 24061. Correspondence should be sent to: lindsayd@vt.edu
\end{abstract}

ABSTRACT: Neospora caninum is a major cause of bovine abortion worldwide. A serological survey was carried out to determine the seroprevalence of exposure to N. caninum in dairy cattle based on age and breed from Punjab and Sindh provinces, Pakistan. Serum samples from 641 animals from 12 herds from Punjab $(n=7)$ and Sindh $(n=5)$ provinces were tested for antibodies against $N$. caninum using a commercially available competitive enzyme-linked immunosorbent assay. Positive reactions to $N$. caninum were seen in $277(43 \%)$ of the 641 of the samples. Seropositive animals were present in all 12 herds. Animals over $2 \mathrm{yr}$ of age $(47 \%)$ and crossbreds $(55 \%)$ were more likely to be seropositive than the other cattle examined. These results indicate that $N$. caninum infection is widespread among dairy cattle in Pakistan.

Neospora caninum is an important cause of abortion in dairy cattle, causing significant economic losses to the industry worldwide (Dubey and Lindsay, 1996). The parasite was recognized in dogs in Norway in 1984 as a cause of neuromuscular degeneration, leading to hind limb paralysis (Bjerkas et al., 1984). Because of structural and antigenic differences from Toxoplasma gondii, it was described as a new species in 1988 (Dubey, Carpenter, et al., 1988) and isolated from naturally infected dogs that same year (Dubey, Hattel, et al., 1988). In 1989 N. caninum was first reported as a cause of bovine abortion (Thilsted and Dubey, 1989). Domestic dogs are definitive hosts for $N$. caninum (McAllister et al., 1998; Lindsay, Dubey, et al., 1999; Lindsay, Upton, et al., 1999). Horizontal transmission of $N$. caninum can result in abortion storms (Thilsted and Dubey, 1989), but vertical (transplacental) transmission of the $N$. caninum is the most economically important outcome of infection (Björkman et al., 1996; Paré et al., 1996; Schares et al., 1998). The majority of congenital infections result in the birth of apparently healthy calves. Cows may abort repeatedly due to $N$. caninum or give birth to apparently healthy calves, calves with subclinical $N$. caninum infection, or uninfected calves. Most congenitally infected calves remain clinically asymptomatic. Most $N$. caninum-induced abortions occur at 5-6 mo of gestation (Dubey, 1999).

Horizontal transmission occurs when cows ingest sporulated $N$. caninum oocysts shed by dogs (McAllister et al., 1998). Domestic dogs are natural definitive hosts for the parasite (McAllister et al., 1998; Lindsay, Dubey, et al., 1999; Lindsay, Upton, et al., 1999). It has been demonstrated that they can become infected by consuming $N$. caninuminfected tissues (Gondim et al., 2002) or bovine placenta (Dijkstra et al., 2001). Experimentally infected dogs excrete few oocysts (Lindsay et al., 2001 ), and the role of dogs and $N$. caninum oocyst excretion is an area of active research in the epizootiology of the disease (Bandini et al., 2011; Cavalcante et al., 2011; King et al., 2012).

Dairy herd health is extremely important to the economy of Pakistan because it is the third largest milk-producing country in the world (FAO, 2009). We have recently reported the seropositivity rate of $N$. caninum in dairy herds with a history of high rates of abortion (Shabbir et al., 2011). Brucella abortus was the most common agent found in aborting cattle (77\%), while $N$. caninum was present in $47 \%$ of aborting animals, and

DOI: $10.1645 / G E-3173.1$ dual infections with these agents were present in $28 \%$ of the animals. However, $N$. caninum was found in $39 \%$ of nonaborting cattle, while $B$. abortus was found in $27 \%$ of nonaborting cattle (Shabbir et al., 2011).

We became interested in determining if horizontal or vertical transmission is more important in maintaining the parasite in the cattle population in Pakistan. In the present study, we examined animals from 3 age groups to consider this question. Additionally, we examined the effects of breed on prevalence to determine if genetic factors may play a role in susceptibility to $N$. caninum. The present study was done in healthy dairy cows from farms in Punjab and Sindh provinces, Pakistan.

Pakistan is an agricultural country, located in southern Asia with hot dry summers, during which temperatures reach over $40 \mathrm{C}$, and mild winters with average temperatures between 15 and $20 \mathrm{C}$. Pakistan is located at latitude between $24^{\circ}$ and $37^{\circ}$ north and longitude between $61^{\circ}$ and $76^{\circ}$ east, and has $803,940 \mathrm{~km}^{2}$ of land, a human population of 1.8 million, and a cattle population of 24.2 million. Between January 2009 and August 2010, serum samples were taken from 641 clinically normal cattle on 12 dairy farms, 7 from Punjab and 5 from Sindh provinces (Tables IIII). Information regarding abortion history was available for only 2 farms (10 and 11). Farm 10 reported abortions in the last year, while farm 11 reported abortions over the last 4 yr. Only 6 cows aborted in herd 10 in the previous year; in herd 11, 21 of the 37 cows had no history of abortion, and the remaining 16 had aborted previously. Some of the cows may have had repeated abortions, but no supporting data were available. Samples were selected from clinically healthy cows of different breeds and different age groups using animal numbers provided by the producers by an individual who had no knowledge of animals status. We sampled 3 age groups of cows, including calves ( $\leq 8 \mathrm{mo}$ of age), heifers ( $>8$ mo to $2 \mathrm{yr}$ old), and adult lactating cows ( $>2 \mathrm{yr}$ old) to determine the variations of serological prevalence against $N$. caninum between different age groups (Table II). Cattle included crossbred (local $\times$ exotic), non-descript (no cross-discernable based on animal appearance), and purebred (Table III). Water and feed were available ad libitum.

Blood was collected from the jugular vein; serum was separated at the Department of Parasitology, University of Veterinary and Animal Sciences, Lahore, Pakistan, and stored at $-20 \mathrm{C}$ until assayed. Serum reactivity to $N$. caninum was evaluated using a commercially available competitive enzyme-linked immunosorbent assay kit (cELISA, VMRD, Pullman, Washington). The procedures were performed according to the manufacturer's instructions, and results were expressed as percent inhibition.

Pearson's $\chi^{2}$ test was used to compare seropositive status with age and breed using (SPSS for Windows, version 13.0; SPSS, Chicago, Illinois), and $P<0.05$ was considered significant.

The cELISA indicated that 277 (43\%) of the 641 cows were seropositive to $N$. caninum. A significant difference $(P<0.05)$ of seropositivity was observed between different herds (Table I). The age of the cows were categorized into 3 groups, below 8 mo of age, 8 mo to $2 \mathrm{yr}$ of age, and above 2 yr old. Neospora caninum seroprevalences were 39\% (37/94), 36\% $(59 / 162)$ and $47 \%(181 / 385)$, respectively. Age-wise prevalence, though not statistically significant $(P>0.05)$, was greatest in animals older than 2 $\mathrm{yr}$ of age (Table II). The prevalence was significantly different $(P<0.05)$ between purebred, crossbred, and non-descript animals. However, no 
TABle I. Prevalence of Neospora caninum in cattle from 12 dairy farms from Pakistan.

\begin{tabular}{ccccc}
\hline $\begin{array}{c}\text { Number } \\
\text { of herds }\end{array}$ & $\begin{array}{c}\text { Number of } \\
\text { cows in the herd }\end{array}$ & $\begin{array}{c}\text { Number of } \\
\text { cows tested }\end{array}$ & Positive & Percentage \\
\hline 1 & 407 & 68 & 31 & 46 \\
2 & 963 & 41 & 13 & 32 \\
3 & 392 & 88 & 33 & 38 \\
4 & 576 & 54 & 19 & 35 \\
5 & 289 & 61 & 33 & 54 \\
6 & 724 & 27 & 16 & 59 \\
7 & 267 & 49 & 18 & 37 \\
8 & 1,271 & 18 & 07 & 39 \\
9 & 875 & 83 & 47 & 57 \\
10 & 219 & 53 & 20 & 38 \\
11 & 86 & 37 & 26 & 70 \\
12 & 694 & 62 & 14 & 23 \\
Total & 6,763 & 641 & 277 & 43 \\
\hline
\end{tabular}

significant difference $(P>0.05)$ was found between sub-breeds, i.e., exotic and local breeds.

The prevalence was not significantly different $(P>0.05)$ within the exotic breeds, i.e., Jersey and Freisian, and local breeds, i.e., Sahiwal, Rojan, Dajal, and Dhanni (Table III). Seroprevalence was highest in crossbred animals (Table III).

The high prevalence of exposure to $N$. caninum (43\%) even in apparently healthy animals indicates that $N$. caninum may be an important risk factor of abortions in these provinces of Pakistan. The seroprevalence of $N$. caninum varies within countries, between regions in countries, and between beef and dairy cattle in areas examined (Dubey et al., 2007). Seroprevalence depends largely on management and environmental conditions of the country being studied (Dubey et al., 2007). The overall high prevalence of $N$. caninum among dairy cattle herds corresponds to previous observations made by Shabbir et al. (2011) who reported high prevalence in aborting animals and in those that were at risk. The prevalence of $N$. caninum in all the age groups strongly suggests transplacental and horizontal transmission (Dubey et al., 2007), but the rate of transmission may be different in different scenarios (Bartels et al., 2007; Dijkstra et al., 2008; Williams et al., 2009).

Sadrebazzaza et al. (2004) concluded that there is no significant relationship between $N$. caninum seropositivity and age. However, Guimaraes et al. (2004) reported that $N$. caninum seropositivity was higher in cattle above $2 \mathrm{yr}$ of age and that horizontal transmission could be responsible for this situation. In the present study, the highest prevalence in age groups over $2 \mathrm{yr}$ agrees with this study and observations made by others that seroprevalence increases with animal age (Dubey et al., 2007; Eiras et al., 2011).

The results of our study showed a significant difference in prevalence of $N$. caninum among different breeds of cattle in our cattle populations and that it was significantly $(P<0.05)$ higher in crossbreds. There are many

TABle II. Prevalence of Neospora caninum antibodies based on cattle age.*

\begin{tabular}{lccc}
\hline & & \multicolumn{2}{c}{ cELISA } \\
\cline { 3 - 4 } Age group & Number of cows tested & Positive & Percentage \\
\hline$\leq 8$ mo old & 94 & 37 & 39 \\
$>8$ mo to 2 yr & 162 & 59 & 36 \\
$>2$ yr & 385 & 181 & 47 \\
\hline
\end{tabular}

* None of the age groups were significantly different $(P>0.05)$ from each other.
TABLE III. Prevalence of Neospora caninum antibodies by cattle breed.

\begin{tabular}{lccccc}
\hline & & & & \multicolumn{2}{c}{ cELISA } \\
\cline { 5 - 6 } & \multirow{2}{*}{ Breed } & & $\begin{array}{c}\text { Number of } \\
\text { cows tested }\end{array}$ & Positive & Percentage \\
\hline \multirow{2}{*}{ Purebred } & \multirow{2}{*}{ Exotic } & Freisian & 77 & 29 & 38 \\
& \multirow{2}{*}{ Local } & Jersey & 45 & 22 & 49 \\
& Sahiwal & 147 & 59 & 40 \\
& Rojan & 24 & 7 & 29 \\
& Dajal & 19 & 6 & 32 \\
Total purebred* & Dhanni & 31 & 11 & 36 \\
Crossbreds $\dagger$ & & 343 & 134 & 39 \\
Non-descript $\$$ & & 213 & 117 & 55 \\
\hline
\end{tabular}

* All 3 breed groups were significantly different $(P<0.05)$ from each other.

$\uparrow$ Local breed crossed with purebred

* Not possible to define breed makeup.

reports worldwide demonstrating differences in seropositivity of different cattle breeds in N. caninum prevalence studies (Armengol et al., 2007; Dubey et al., 2007; Duong et al., 2008; Munhoz et al., 2009). However, these reports should be interpreted carefully because production systems may be a possible explanation rather than breed-related susceptibility. The extent of abortion and immune responses after $N$. caninum infection is likely affected by the breed of cattle (Armengol et al., 2007; Almeria et al., 2009; Romero-Salas et al., 2010; Santolaria et al., 2011). Experimental studies need to be conducted with different bovine breeds before the influence of breed can be accurately evaluated and its importance in the epizootiology of bovine $N$. caninum infections can be determined.

\section{LITERATURE CITED}

Almeria, S., F. Lopez-Gatius, I. Garcia-Ispierto, C. Nogareda, G. Bech-Sabat, B. Serrano, P. Santolaria, and J. L. Yaniz. 2009. Effects of crossbreed pregnancies on the abortion risk of Neospora caninum-infected dairy cows. Veterinary Parasitology 163: 323-329.

Armengol, R., M. Pabon, P. Santolaria, O. Cabezon, C. Adelantado, J. Yaniz, F. Lopez-Gatius, and S. Almeria. 2007. Low seroprevalence of Neospora caninum infection associated with the Limousin breed in cow-calf herds in Andorra, Europe. Journal of Parasitology 93: $1029-1032$.

Bandini, L. A., A. F. Neto, H. F. Pena, G. T. Cavalcante, G. Schares, S. M. Nishi, AND S. M. Gennari. 2011. Experimental infection of dogs (Canis familiaris) with sporulated oocysts of Neospora caninum. Veterinary Parasitology 176: 151-156.

Bartels, C. J. M., I. Huinink, M. L. Beiboer, G. van Schaik, W. Wouda, T. Dijkstra, and A. Stegeman. 2007. Quantification of vertical and horizontal transmission of Neospora caninum infection in Dutch dairy herds. Veterinary Parasitology 148: 83-92.

Bjerkas, I., S. F. Mohn, and J. Presthus. 1984. Unidentified cyst-forming sporozoon causing encephalomyelitis and myositis in dogs. Zeitschrift für Parasitenkunde 70: 271-274.

Björkman, C., O. Johansson, S. Stenlund, O. J. Holmdahl, and A. UGGLA. 1996. Neospora species infection in a herd of dairy cattle. Journal of the American Veterinary Medical Association 208: 14411444.

Cavalcante, G. T., R. M. Monteiro, R. M. Soares, S. M. Nishi, A. F. Alves Neto, O. Esmerini Pde, M. K. Sercundes, J. Martins, and S. M. GenNari. 2011. Shedding of Neospora caninum oocysts by dogs fed different tissues from naturally infected cattle. Veterinary Parasitology 179: 220-223.

Dijkstra, T., M. Eysker, G. Schares, F. J. Conraths, W. Wouda, and H. W. Barkema. 2001. Dogs shed Neospora caninum oocysts after ingestion of naturally infected bovine placenta but not after ingestion of colostrum spiked with Neospora caninum tachyzoites. International Journal for Parasitology 31: 747-752. 
T. J. G. M. Lam, C. J. M. Bartels, M. Eysker, and W. Wouda. 2008. Natural postnatal Neospora caninum infection in cattle can persist and lead to endogenous transplacental infection. Veterinary Parasitology 152: 220-225.

Dubey, J. P. 1999. Recent advances in the Neospora and Neosporosis. Veterinary Parasitology 84: 349-367.

- J. L. Carpenter, C. A. Speer, M. J. Topper, and A. Uggla. 1988. Newly recognized fatal protozoan disease of dogs. Journal of the American Veterinary Medical Association 192: 1269-1285.

- A. L. Hattel, D. S. Lindsay, and M. J. Topper. 1988. Neonata Neospora caninum infection in dogs: Isolation of the causative agent and experimental transmission. Journal of the American Veterinary Medical Association 193: 1259-1263.

— AND D. S. Lindsay. 1996. A review of Neospora caninum and neosporosis. Veterinary Parasitology 67: 1-59.

-, G. Schares, and L. M. Ortega-Mora. 2007. Epidemiology and control of Neosporosis and Neospora caninum. Clinical Microbiology Reviews 20: 323-367.

Duong, M. C., S. Alenius, L. T. T. Huong, and C. Biorkman. 2008. Prevalence of Neospora caninum and bovine viral diarrhoea virus in dairy cows in southern Vietnam. Veterinary Journal 175: 390-394.

Eiras, C., I. Arnaiz, G. Alvarez-Garcia, L. M. Ortega-Mora, M. L. Sanjuanl, E. Yus, And F. J. Dieguez. 2011. Neospora caninum seroprevalence in dairy and beef cattle from the northwest region of Spain, Galicia. Preventive Veterinary Medicine 98: 128-132.

FAO. 2009. The Cattle Site, 5M Enterprises Limited 2000-2012. 5m Publishing, Benchmark House, Sheffield, England. http://www thecattlesite.com. Accessed 14 January 2013.

Gondim, L. F., L. GaO, And M. M. McAllister. 2002. Improved production of Neospora caninum oocysts, cyclical oral transmission between dogs and cattle, and in vitro isolation from oocysts. Journal of Parasitology 88: 1159-1163.

Guimaraes, J. S., S. L. P. Souza, D. P. Bergamaschi, and S. M. Gennari. 2004. Prevalence of Neospora caninum antibodies and factors associated with their presence in dairy cattle of the north of Paraná State, Brazil. Veterinary Parasitology 124: 1-8.

King, J. S., G. K. Brown, D. J. Jenkins, J. T. Ellis, P. J. Fleming, P. A Windsor, and J. Slapeta. 2012. Oocysts and high seroprevalence of Neospora caninum in dogs living in remote Aboriginal communities and wild dogs in Australia. Veterinary Parasitology 187: 85-92.

Lindsay, D. S., J. P. Dubey, And R. B. Duncan. 1999. Confirmation that the dog is a definitive host for Neospora caninum. Veterinary Parasitology 82: 327-333.

, D. M. Ritter, And D. Brake. 2001. Oocyst excretion in dogs fed mouse brains containing tissue cysts of a cloned line of Neospora caninum. Journal of Parasitology 87: 909-911.
S. J. Upton, and J. P. Dubey. 1999. A structural study of the Neospora caninum oocyst. International Journal for Parasitology 29: $1521-1523$.

McAllister, M. M., J. P. Dubey, D. S. Lindsay, R. W. Jolley, A. R. Wills, And M. A. McAguirre. 1998. Dogs are definitive hosts of Neospora caninum. International Journal for Parasitology 28: 1473 1478.

Munhoz, A. D., M. J. S. Pereira, W. Flausino, and C. W. G. Lopes. 2009. Neospora caninum seropositivity in cattle breeds in the South Fluminense Paraiba Valley, state of Rio de Janeiro. Pesquisa Veterinária Brasileira 29: 29-32.

Paré, J., M. C. Thurmond, and S. K. Hietala. 1996. Congenital Neospora caninum infection in dairy cattle and associated calfhood mortality. Canadian Journal of Veterinary Research 60: 133-139.

Romero-Salas, D., Z. Garcia-Vazquez, F. Montiel-Palacios, T. Montiel-Péna, M. Aguilar-Dominguez, L. Medina-Esparza, and C. Cruz-Vazquez. 2010. Seroprevalence of Neospora caninum antibodies in cattle in Veracruz, Mexico. Journal of Animal Veterinary Advances 9: 1445-1451.

Sadrebazzaza, A., H. Haddadzadehb, K. Esmailniac, G. Habibic, M. Vojganib, and R. Hashemifesharakic. 2004. Serological prevalence of Neospora caninum in healthy and aborted dairy cattle in Mashhad, Iran. Veterinary Parasitology 124: 201-204.

Santolaria, P., S. Almeria, D. Martinez-Bello, C. Nogareda, M. Mezo, M. Gonzalez-Warleta, J. A. Castro-Hermida, M. Pabon, J. L. YAniz, And F. Lopez-Gatius. 2011. Different humoral mechanisms against Neospora caninum infection in purebreed and crossbreed beef/dairy cattle pregnancies. Veterinary Parasitology 178: 70 76.

Schares, G., M. Peters, R. Wurm, A. Bärwald, and F. J. Conraths 1998. The efficiency of vertical transmission of Neospora caninum in dairy cattle analysed by serological techniques. Veterinary Parasitology 80: $87-98$.

Shabbir, M. Z., M. Nazir, A. Maqbool, M. Lateef, M. A. B. Shabbir, A. Ahmad, M. Rabbani, T. Yaqub, M. U. Sohail, and M. IJaz. 2011 Seroprevalence of Neospora caninum and Brucella abortus in dairy cattle herds with high abortion rates. Journal of Parasitology 97: 740 742 .

Thilsted, J. P., And J. P. Dubey. 1989. Neosporosis-like abortions in a herd of dairy cattle. Journal of Veterinary Diagnostic Investigation 1: 205-209.

Williams, D. J. L., C. S. Hartley, C. Buorkman, and A. J. Trees. 2009 Endogenous and exogenous transplacental transmission of Neospora caninum - How the route of transmission impacts on epidemiology and control of disease. Parasitology 136: 1895-1900. 